\title{
THE POSITION OF STUDENTS' ERRORS IN ALGEBRAIC PROBLEM- SOLVING BASED ON FIELD DEPENDENT AND INDEPENDENT
}

\author{
Aloisius Loka Son ${ }^{1}$, Darhim², Siti Fatimah ${ }^{3}$ \\ ${ }^{1}$ Universitas Timor, Jln. KM.9, Kefamenanu, Indonesia. \\ aloisiuslokason@unimor.ac.id \\ ${ }^{2}$ Universitas Pendidikan Indonesia, J1. Dr. Setiabudi No.229, Bandung, Indonesia. \\ darhim0355@gmail.com \\ ${ }^{3}$ Universitas Pendidikan Indonesia, Jl. Dr. Setiabudi No.229, Bandung, Indonesia. \\ sitifatimah@upi.edu
}

\begin{abstract}
There is a strong relationship between field-dependent (FD), field-independent (FI) cognitive styles, and problem-solving performance. FD students are more oriented towards the outside world, while FI students rely more on their knowledge and experience. The present study aimed to reveal the position of the FI and FD student's errors in algebraic problem-solving. The subjects of this study were 27 students of class VII in one of the Junior High Schools in Kefamenanu, Indonesia, Academic Year 2018/2019. Data collection involved tests of algebraic problem-solving ability, interviews, and Group Embedded Figure Test. The case study results showed that the algebraic problem-solving abilities of FI students were better than FD students. The scores of algebraic problem-solving abilities of FI students were dominant in the medium and high categories. In contrast, the FD students were dominant in the medium and low categories. Also, FI students predominantly committed proceduralerrors. Whereas, most FD students made errors on all types of errors, specifically factual, conceptual, and procedural errors. Thus, it is recommended that FI and FD students' algebraic problem-solving ability become the focus of attention and importance to characterize them as a basis for further research .
\end{abstract}

ARTICLE INFORMATION

\begin{tabular}{|c|c|}
\hline Keywords & Article History \\
\hline $\begin{array}{l}\text { Algebraic problem-solving } \\
\text { Position of error } \\
\text { Field-dependent } \\
\text { Field-independent }\end{array}$ & $\begin{array}{l}\text { Submitted Nov 26, } 2020 \\
\text { Revised Mar 10, } 2021 \\
\text { Accepted Mar 22, } 2021\end{array}$ \\
\hline Corresponding Author & \\
\hline $\begin{array}{l}\text { Aloisius Loka Son } \\
\text { Universitas Timor } \\
\text { Jl. El Tari - KM. 09, Kefamenanu, Indonesia } \\
\text { Email: aloisiuslokason@unimor.ac.id }\end{array}$ & \\
\hline How to Cite & \\
\hline
\end{tabular}

https://doi.org/10.22236/KALAMATIKA.vol6no1.2021pp57-70

\section{(cc) $)$ BY-SA}

This work is licensed under a Creative Commons Attribution - ShareAlike 4.0 International 


\section{INTRODUCTION}

Recently, the need to understand and be able to use mathematics in everyday life will continue to increase as a part of cultural heritage, the workplace, the scientific and technical community (NCTM, 2000). Therefore, mathematics becomes one of the compulsory subjects in formal schools, ranging from elementary school to college. However, in reality, mathematics is still considered a scary subject, which has an impact on the low achievement of Indonesian students' mathematical abilities. As reported by Trends in International Mathematics and Science Study (TIMSS), in 2015, Indonesian students ranked $45^{\text {th }}$ out of 50 participating countries (IEA, 2016). Other international institutes that assess students' mathematical abilities are the Program for International Student Assessment (PISA), which reported that, in 2018, Indonesian students ranked $72^{\text {th }}$ out of 78 participating countries (OECD, 2019). Besides the TIMMS and PISA results, the Indonesia Ministry of Education and Culture's central report on the national examination results showed that the national average math score in 2018 is 43.34 (Puspendik, 2018).

One of the specific branches of mathematics as a domain of assessments carried out by TIMMS, PISA, and national examinations is Algebra. This shows the importance of Algebra in mathematical calculations and as a basis for solving mathematical problems. Almost all fields of mathematics require algebra as a problem-solving tool (Agoestanto, et al., 2019). Algebra is the beginning of a journey that provides skills to solve more complex problems. Knowledge of algebraic concepts and skills is a prerequisite for students to develop higherorder thinking and problem-solving skills in real-life situations (Ganesen, et al., 2020).

Algebra is a branch of mathematics. The reports on the results of TIMSS, PISA, and national exams showed that the mathematics achievement and the algebraic ability of Indonesian students were poor and still far from expected. One of the evidence is the results of a national exam at a state junior high school in the city of Kefamenanu. In 2018, the average algebraic material mastery of students at the school was 31.28. It was even lower than 2017, which amounted to 43.48. While nationally, the average mastery of students' algebraic material was 41.88, lower than in 2017, which was 46.60 (Puspendik, 2017., 2018). If this problem is not resolved, it will prevent students from learning algebraic material in the next stages.

Results description of the TIMSS, PISA, and national exam showed that the algebraic 
ability in particular and the mathematical abilities in general of Indonesian students at the international and national levels were not as expected. Indonesian students did not have the readiness to face challenges in real life because the assessment conducted by TIMSS makes students think of the importance of success in school and success in future careers (Mullis, et al., 2004). Whereas the assessment carried out by PISA aims to measure the readiness of the younger generation to meet real challenges of contemporary life (Anderson, et al., 2009).

Based on the issues above, in learning mathematics at schools, students are required to habituate themselves in solving problems. Problem-solving should be a core objective of teaching mathematics in schools (García, et al., 2019) because by this way then the students can learn to apply their math skills in new ways, they will develop a deeper understanding of mathematical ideas, and experience being a mathematician (Badger, et al., 2012). The process of solving a problem requires the application of a solution strategy, which can direct the problem solver to explore many ideas in obtaining solutions to a problem. One of the popular problem-solving processes is the methods according to Polya (1957), consisting of understanding the problem, devising a plan, carrying out the plan, and looking back.

Problem-solving abilities are skills that students must master. Their errors become obstacles in developing their thinking to solve math problems. Therefore, it is necessary to analyze the position of students' mathematical problem-solving errors to minimize them from being repeated (Agoestanto, et al., 2019). This information is used to identify at which point in the problem-solving task students experience difficulty or frustration (Brown \& Skow, 2016). Furthermore, they said that the types of errors that students often make in solving math problems are factual errors, conceptual errors, and procedural errors. Factual errors are errors due to the lack of factual information. Procedural errors are errors due to incorrect performance of steps in a mathematical process. Whereas conceptual errors are errors due to misconception or a faulty understanding of the underlying principles and ideas connected to the mathematical problems.

Students' problem-solving ability in mathematics can be seen from several dimensions, one of them is a cognitive style (Ulya \& Retnoningsih, 2014). Most of the research showed that students with different cognitive styles have ways of different processing information and problem-solving (Witkin \& Goodenough, 1981). Researchers around the world are very interested in studying the relationship between dimensions of cognitive style with 
mathematical abilities (Chrysostomou, et al., 2011).

The cognitive style emphasizes a person's characteristics in respond, processing, storing, thinking, and using the information to question multiple tasks (Carraher, 2017). The most popular cognitive styles are the field-independent (FI) and field-dependent (FD) cognitive styles (Mefoh, Nwoke, \& Chijioke, 2017). FI and FD cognitive styles are characterized by common ways of thinking, solving problems, learning, and relating to other people (Abrams \& Belgrave, 2013). Pithers (2006) stated that there is a strong relationship between FI-FD cognitive style and problem-solving performance. Based on these reasons, then this study was conducted to reveal the position of the FI and FD student's errors in algebraic problem-solving.

\section{METHOD}

The research used a qualitative research method with a case study approach, particularly collective case studies. The studies will reveal deviations from the reasonableness of a phenomenon, population, or general condition (Creswel, 2012). The subjects of this study were 27 Year 7 students from one of the Junior High Schools in Kefamenanu City-Indonesia, Academic Year 2018/2019. They consisted of 12 male and 15 female students, who were taught by the same mathematics teacher, and had the same average age.

The data collection sources were tests of algebraic problem-solving ability, interviews, and Group Embedded Figure Test (GEFT). Algebraic problem-solving ability tests and interviews were conducted to reveal the position of students' errors in solving algebraic problems. The test consisted of 4 questions in the form of essays. The assessment guidelines referred to indicators of problem-solving ability based on Polya's principles. While the interviews were semi-structured by questioning what, why, and how students' errors. GEFT was developed by Witkin in 1971 and used to classify types of cognitive styles based on psychological differences, namely the FI and FD cognitive styles. GEFT consisted of three parts that part I consisted of seven questions, part II and part III each consisted of nine questions. Part I was an exercise, while the scores were calculated from part II and part III.

The data analysis technique used was the triangulation technique. The qualitative study relied on the triangulation of the resulting data (Chariri, 2009). Triangulation is the process of corroborating evidence from different types of data (Creswell, 2012). Strengthening the evidence in this study intended to check the accuracy of the results and interpret data to the 
same source with different techniques through the analysis of student work and interviews. Triangulation activities were carried out through the stages of data reduction, data display, and conclusions.

\section{RESULT AND DISCUSSION}

The results test of the 27 students obtained 10 FI students and 17 FD students of the cognitive style. While the test results of students' algebraic problem-solving ability, the obtained average was 17.63 , the standard deviation was 6.76 , the maximum score was 28 , and the minimum score was 8 from an ideal maximum standard of 36. Based on this average and standard deviation, student scores were grouped into high, medium, and low categories. The nine students scored in the high category, 13 in the medium category, and five in the low category. The percentage of the high and medium scores of FI students were 30\% and 7\%, respectively and no FI students scored in the low category. Whereas for FD students, $4 \%$ of students scored in the high category, $41 \%$ of the medium category, and $18 \%$ of the low category.

The results of students' work were then analyzed qualitatively to examine the errors made by students. Types of student errors were categorized as factual errors, conceptual errors, and procedural errors. Based on these types of errors, it can be described and given the coding of the errors made by students. Factual errors consisted of the students who were not able to describe the elements that are known in the algebraic problem $\left(\mathrm{F}_{1}\right)$, students that were not able to identify the instructions that exist in the algebraic problem (name and meaning of symbols, and properties) $\left(\mathrm{F}_{2}\right)$, and who did not understand the algebraic problem asked $\left(\mathrm{F}_{3}\right)$. Conceptual errors consisted of students who could not determine the formula for solving algebraic problems $\left(\mathrm{C}_{1}\right)$ and students who were not able to use the formula to solve the algebraic problem correctly $\left(\mathrm{C}_{2}\right)$. While procedure errors consisted of the students who were not able to do mathematical operations $\left(\mathrm{P}_{1}\right)$, and who were not able to solve algebraic problems systematically (technically) $\left(\mathrm{P}_{2}\right)$.

All of the test results of students' algebraic problem-solving ability can be analyzed based on the type of error with coding above. Recapitulation of student errors in solve algebraic problem-solving tests is described in Table 1.

Table 1. Percentage of students who make algebraic problem-solving errors

\begin{tabular}{llllllll}
\hline \multirow{2}{*}{ QN } & \multirow{2}{*}{$\mathrm{CS}$} & \multicolumn{7}{c}{ Students' errors type (\%) } \\
\cline { 2 - 8 } & $\mathrm{F}_{1}$ & $\mathrm{~F}_{2}$ & $\mathrm{~F}_{3}$ & $\mathrm{C}_{1}$ & $\mathrm{C}_{2}$ & $\mathrm{P}_{1}$ & $\mathrm{P}_{2}$ \\
\hline
\end{tabular}




\begin{tabular}{rlrrrrrrr}
\hline \multirow{2}{*}{1} & FI & 3.70 & 3.70 & 0.00 & 3.70 & 7.41 & 14.81 & 22.22 \\
& FD & 22.22 & 25.93 & 11.11 & 29.63 & 25.93 & 51.85 & 55.56 \\
2 & FI & 3.70 & 0.00 & 3.70 & 7.41 & 7.41 & 14.81 & 22.22 \\
& FD & 33.33 & 33.33 & 33.33 & 33.33 & 40,74 & 55.56 & 62.96 \\
3 & FI & 0.00 & 3.70 & 0.00 & 3.70 & 7.41 & 11.11 & 11.11 \\
& FD & 0.00 & 25.93 & 0.00 & 33.33 & 40.74 & 55.56 & 62.96 \\
\multirow{2}{*}{4} & FI & 0.00 & 0.00 & 0.00 & 3.70 & 3.70 & 0.00 & 11.11 \\
& FD & 37.04 & 37.04 & 37.04 & 40.74 & 55.56 & 55.56 & 59.26 \\
\hline \multirow{2}{*}{ AP } & FI & 1.85 & 1.85 & 0.93 & 4.63 & 6.48 & 10.18 & 16.67 \\
& FD & 23.15 & 30.56 & 20.37 & 34.26 & 42.59 & 53.71 & 57.41 \\
\hline \multicolumn{7}{l}{ QN: Question Number, CS: Cognitive Style, AP: Average of Percentage }
\end{tabular}

The table 1 above showed the average percentage of students who made algebraic problem-solving errors, FI students who made $\mathrm{F}_{1}$ errors were $1.85 \%$, while the FD students were $23.15 \%$. The average percentage of FI students who made $\mathrm{F}_{2}$ errors was $1.85 \%$, whereas the FD students were $30.56 \%$. FI students who made $\mathrm{F}_{3}$ errors, the average percentage were $0.93 \%$, the FD students were $20.37 \%$. FI students who made $\mathrm{C}_{1}$ errors were $4.63 \%$, while the FD students were $34.26 \%$. Next, FI students who made $\mathrm{C}_{2}$ errors were $6.48 \%$, and the FD students were $42.59 \%$. The average percentage of FI students who made $\mathrm{P}_{1}$ error was $10.18 \%$, while the FD students were $53.71 \%$, and the average percentage of FI students who made $\mathrm{P}_{2}$ error was $16.67 \%$, while the FD students were $57.41 \%$. This descriptive statistic revealed that FD students made more errors in algebraic problem-solving than FI students. The type of errors that FI students often made was procedural errors, while FD students tended to make all the errors from factual errors to procedural errors.

Based on the descriptive statistics in Table 1, the researchers conducted interviews with four students to confirm the suitability of their answers. The four students consist of two from both FI and FD students. Determining them according to the basic errors made by students. In this study, the researchers only displayed one work of FI and FD students on item number 1 . The following is problem 1.

Look at the following plane figure!

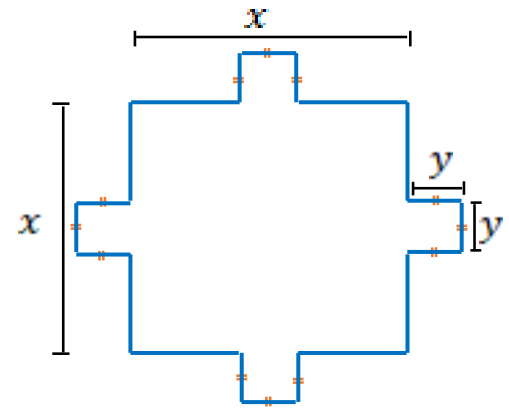

Find the area of the plane figure above! 
The answers of FI and FD students on item number 1 are presented in Figure 1.

\begin{tabular}{l} 
Jawab: $\quad x \quad I$ \\
\hline$x$ \\
\hline$I=X \cdot X=x^{2}$ \\
$L I=4 \cdot y^{2}=4 y^{2}$ \\
$L I+I=x^{2}+4 y^{2}$ \\
Jadi luas daerah bangun di atas $=x^{2}+4 y^{2}$
\end{tabular}

FI student

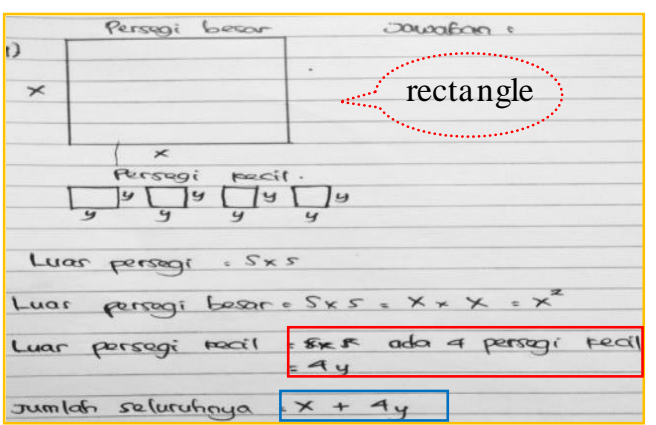

FD student

Figure 1. Students' answers on the question to number 1

Figure 1 shows that FI student did not describe the elements that are known in algebraic problem and asked in questions ( $\mathrm{F}_{1}$ and $\mathrm{F}_{3}$ errors), but the student has been able to divide it separately into several parts and grouped them into several groups of squares with the length of $\mathrm{x}$ side, and groups of squares with the length of side $\mathrm{y}$. In the next step, the FI student devised the formula to determine each square's area and the total area of the figure.

While FD student could not describe the elements that are known and asked $\left(\mathrm{F}_{1}\right.$ and $\mathrm{F}_{3}$ errors). In the plane figure given, the FD student divided it separately into several parts, and grouped them in rectangle groups with length and width are same i.e., $\mathrm{x}$ (the plane was a rectangle), and groups of rectangles with length and width are same i.e., y (The shapes were rectangle). Though $\mathrm{FD}$ student made errors $\mathrm{F}_{1}, \mathrm{~F}_{2}$, and $\mathrm{F}_{3}$, but in the following steps, FD student devised the plan by writing the formula to determine the area of each rectangle which was s x s, and determined the rectangle area (big plane) i.e., $\mathrm{x}^{2}$, but it was wrong in figuring the area of four rectangles (small plane). It is affected the miscalculation of the overall plane area, even the plane area (big) i.e., $\mathrm{x}^{2}$ was written in the form of $\mathrm{x}$. The plane area obtained by FD students was $4 \mathrm{x}+4 \mathrm{y}$.

Based on FI and FD students' answers in Figures 1, the researcher continued with an interview to confirm the students' answers. In this article, the author only displayed the results of interviews with one of FI and FD student on item question number 1. The results of interviews with FI students are presented in Table 2.

Table 2. Excerpts of the results of interviews with FI student

\begin{tabular}{ll}
\hline \multicolumn{1}{c}{ Researcher } & \multicolumn{1}{c}{ FI student } \\
\hline $\begin{array}{l}\text { Look at question number 1! From this problem, try to } \\
\text { explain the elements that are known and asked! }\end{array}$ & This is what is known, sir (pointing to the figure of the airplane in question). \\
$\begin{array}{l}\text { What do you have to do to determine the area of the } \\
\text { plane? }\end{array}$ & $\begin{array}{l}\text { This problem asks the plane's irregular area, sir. } \\
\text { area of each part, and then added up to get ans wers to the questions. }\end{array}$
\end{tabular}


Why does it have to be divided (separated)?

You can try to cut (separate) the plane! What formula can you use to calculate the area of each part?

Try to calculate the area of each plane!

Why is the $\mathrm{L}_{2}$ formula multiplied by 4 ? Try to write the area of the plane figure asked in the problem!
Yes, because the plane figure is known are an irregular plane. There is no specific plane area formula that can be used.

(The Student drew the plane figure separately, there were a square with sidex, and 4 squares with side $y$ ), then explained that the square area formula with side $\mathrm{x}$ is $x \times x$, and the square area formula with side $\mathrm{y} \operatorname{was} \times \mathrm{x}$. (student write and explain)

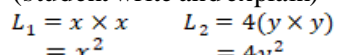

Because the number of squares with sidey is 4 squares, sir. The area of the plane figure is: $L=x^{2}+4 y^{2}$ unit of area

The interview results in Table 2 show that FI student was able to describe the elements known and asked, identify the plane by separating it into several parts precisely, determine the formula to calculate the area of each square, and then use the formula of the square area in the solving process. The student accomplished the mathematical operations and solved algebraic problems systematically. The explanations from FI student were the same as the answer that is written on the paper. The answer to the following question matched the solution step when the written test. This showed that the FI student did not make an error in the problem-solving question of number 1 .

The excerpts of the interview results with FD student will be presented in Table 3 . The results showed that FD student understood the elements that were asked in the question but was not able to describe it. As a result of not describing known elements, the FD student drew each part of the plane figures separately and drawn it as a rectangle. In the next step, the FD student determined the formula used to calculate the area of each square but was unable to apply the formula in the calculation process $\left(\mathrm{C}_{2}\right.$ error). The effect of this $\mathrm{C}_{2}$ error, so FD student continued to make errors at $\mathrm{P}_{1}$ and $\mathrm{P}_{2}$, was unable to systematically accomplish the mathematical operations and systematically solve the problems.

Table 3. Excerpts of the results of interviews with FD student

\begin{tabular}{|c|c|}
\hline Researcher & FD student \\
\hline Look at question number 1 ! From this problem, try to explain & What the known is a picture (pointing to the plane figure in the problem) \\
\hline $\begin{array}{l}\text { the elements that are known and asked! } \\
\text { What do you have to do to determine the area of the plane? }\end{array}$ & $\begin{array}{l}\text { From this picture, what should be calculated is the area, sir. } \\
\text { Divide (separated) sir. (students then draw it separately into several parts, } \\
\text { but all parts are drawn in the rectan gular form) }\end{array}$ \\
\hline Why does it have to be divided (separated)? & So that we can calculate the area of each of these planes, sir. \\
\hline $\begin{array}{l}\text { What formula should be used to calculate the area of each of } \\
\text { these planes? }\end{array}$ & Side $\mathrm{x}$ side, sir. \\
\hline Why is the formula side $\mathrm{x}$ side? & $\begin{array}{l}\text { (The student was silent), then directed by researchers that the picture is a } \\
\text { square, not a rectangle. }\end{array}$ \\
\hline Try to calculate the area of each plane! & $\begin{aligned} L_{I} & =x \times x \quad L_{I I}=4(y \times y) \\
& =2 x \quad=4 y \\
L & =L_{I}+L_{I I}=2 x+4 y\end{aligned}$ \\
\hline Try to explain why the area $L_{l}$ is $2 \mathrm{x}$, and $L_{2}$ is $4 \mathrm{y}$ ? & This $2 \mathrm{x}$ is a large plane area, and $4 \mathrm{y}$ is a small plane area, sir. \\
\hline $\begin{array}{l}\text { Try to determine the results of } x \times x=\cdots, \text { and } y \times y=\cdots ! \\
\text { Look at this! If } x \times x=x^{2} \text {, then } y \times y=\cdots \text { ? }\end{array}$ & $\begin{array}{l}\text { I do not know, sir. } \\
\text { Student ans wer: } y^{2}\end{array}$ \\
\hline Try to write the area of the plane figure asked in the problem! & Student writes: $L=x^{2}+y^{2}$ \\
\hline
\end{tabular}


In general, this study showed that FI students made fewer errors in solving algebraic problems than FD students. In line with the research results by Agoestanto, et al. (2019), students with the FI cognitive style had fewer errors in working on algebraic thinking skills than students with the FD cognitive style. The average of the algebraic problem-solving ability of FI students in the category was good, namely being able to describe the elements known, to identify the instructions that exist in algebraic problem, to understand the asked elements, to determine and to use the formula of solving the algebraic problems correctly, to do mathematical operations, and being able to solve the problems systematically, even though sometimes they did procedural errors. Consistent with the research results that FI students can fulfill all of the indicators problem-solving, although sometimes made an error in some indicators (Ulya \& Retnoningsih, 2014., Anthycamurty et al., 2018).

The algebraic problem-solving ability of FD students was still low because almost all FD students made all types of errors; specifically they were not able to describe the elements that are known, to identify the instructions that exist in the algebraic problem-solving question (name, the meaning of symbols, and properties), did not understand the asked elements, not able to determine and to use the formula in solving the algebraic problem correctly, not able to do mathematical operations and solve the algebraic problems systematically. Mostly, FD students' abilities were low, although occasionally, some FD students did not make errors for certain types of errors.

The measurement of algebraic problem-solving ability in this study used Polya's indicators, and FD students could not solve mathematics problems according to these indicators. This result line with the research done by Ulya \& Retnoningsih (2014) and Anthycamurty et al. (2018); they said that FD students have not met almost all indicators of problem-solving based on Polya's indicators. They were not clear enough in making a device a plan and cannot accomplish the problem in all Polya steps (Hartanto \& Mariani, 2019).

The difference in algebraic problem-solving ability between FI and FD students occurred because FI and FD students' characteristics were inclined to be different. Students with FD cognitive style found difficulties in processing information and experienced struggling when information need to be manipulated in a different context. FD students' perceptions were weak when the context changed. Meanwhile, FI students tended to use internal factors as directions in processing information. FD students were more accepting the 
existing structure due to lack of restructuring; they tended to follow existing goals and work with external motivation. They were more interested in external reinforcement such as praise, gifts, or external motivation from others. In the meantime, FI students were generally more independent, competitive, and confident in their abilities (Karaçam \& Baran, 2015; Witkin, et al., 1977). They relied on their knowledge and experience, while FD students were more oriented to the outside world (external motivation) when solving problems (Volkova \& Rusalov, 2016).

In the process of learning mathematics in schools, one thing that must get attention is the difference in the tendencies of FI and FD students, especially FD students who have the problem-solving ability that tends to be lower than FI students. Mathematics teachers need to consider the learning models, strategies, approaches, and methods used in the learning process in facilitating the mathematical problem-solving ability of FD students. Furthermore, the important thing that needs to be examined in learning mathematics is to provide FD students opportunities to discuss more with their classmates. This will allow an increase in their problem-solving ability because it is supported by their characteristics, who are more likely to socialize and get together with the people around them (Karaçam \& Baran, 2015., Volkova \& Rusalov, 2016). These characteristics allow their problem-solving abilities to develop by providing opportunities for them to learn together.

\section{CONCLUSION}

Based on the research results and discussion above, it can be concluded that the algebraic problem-solving ability of FI students was better than FD students. This is seen based on the score of algebraic problem-solving ability of the FI students were dominant in the medium and high categories, while the scores of the algebraic problem-solving ability of the FD students were dominant in the medium and low categories. FI students were able to describe the elements that are known, identify the instructions that exist in algebraic problemsolving question, understood the problem being asked, be able to determine and use the formula for algebraic solving-problems correctly, being able to accomplish mathematical operations and solve algebraic problems systematically. However, sometimes FI students made some procedural errors. Most FD students made errors on all types of errors, such as not being able to describe the known elements, identify the instructions in the algebraic problem (name and meaning of symbols, and properties), understand the problem asked, determine the 
formula and use it in solving algebraic problem correctly, do mathematical operations and solve algebraic problems systematically (technical). However, some FD students did not make these certain types of errors.

Therefore, it is recommended to consider using learning models, strategies, approaches, and methods to facilitate the algebraic problem-solving ability of FI and FD students, especially FD students who have lower algebraic problem-solving ability than FI students. The teachers can minimize the differences in mathematical abilities between these two cognitive style groups. Besides, it is suggested that FI and FD students' algebraic problem-solving ability becomes the focus of attention. It is important to be characterized as a basis for further research.

\section{REFERENCES}

Abrams, J., \& Belgrave, F. Z. (2013). Field Dependence. The Encyclopedia of Cross-Cultural Psychology, II(1), 1-3. https://doi.org/10.1002/9781 11833 9893.wbeccp221.

Agoestanto, A., Sukestiyarno, Y. L., Isnarto, Rochmad, \& Lestari, M. D. (2019). The Position and Causes of Students Errors in Algebraic Thinking Based on Cognitive Style. International Journal of Instruction, 12 (1), 1431-1444.

Anderson, J, Milford, T., \& Ross, S. P. (2009). Multilevel Modeling with HLM: Taking a Second Look at PISA. Quality Research in Literacy and Science Education: International Perspectives and Gold Standards, 263-286.

Anthycamurty, C. C., Mardiyana, \& Saputro, D. R. S. (2018). Analysis of Problem Solving in Terms of Cognitive Style. International Conference on Mathematics, Science and Education, 83, 1-5. https://d oi.org/10.1088/1742-6596/983/1/012146.

Badger, M., Sangwin, C. J., Hawkes, T. O., Burn, R. P., Mason, J., \& Pope, S. (2012). Teaching Problem-Solving in Undergraduate Mathematics. Coventry, UK: Coventry University.

Brown, J., \& Skow, K. (2016). Mathematics: Identifying and Addressing Student Errors. In The Iris Center. United States of America: The Iris Center.

Carraher, E., Smith, R. E., \& De Lisle, P. (2017). Cognitive Styles. In E. Carracer \& P. De 
Lisle (Editors), Leading Collaborative Architectural Practice (pp. 179-195). New Jersey: Jhon Wiley \& Sons.

Chariri, A. (2009). Landasan Filsafat dan Metode Penelitian Kualitatif. Semarang: Universitas Diponegoro.

Chrysostomou, M., Tsingi, C., Cleanthous, E., \& Pitta-Pantazi, D. (2011). Cognitive Styles and Their Relation to Number Sense and Algebraic Reasoning. Proceedings of the Seventh Congress of the European Society for Research in Mathematics Education, 387-396.

Creswell, J. W. (2012). Educational Research, Planning, Conducting and Evaluating Quantitative and Qualitative Research. USA:Pearson.

Ganesen, P., Osman, S., Abu, M. S., \& Kumar, J. A. (2020). The Relationship Between Learning Styles and Achievement of Solving Algebraic Problems Among Lower Secondary School Students. International Journal of Advanced Science and Technology, 29 (95), 2563-2574.

García, T., Boom, J., Kroesbergen, E. H., Nunez, J. C., \& Rodriguez, C. (2019). Planning, Execution, and Revision in Mathematics Problem Solving: Does the Order of the Phases Matter? Studies in Educational Evaluation Journal, 83-93. https://doi.org/10.1016/j.stueduc.2019.03.001.

Hartanto, F. D., \& Mariani, S. (2019). An Analysis of Mathematical Problem Solving Ability in Terms of Students' Cognitive Style in Learning PBL Includes Ethnomathematics. Unnes Journal of Mathematics Education Research, 8(1), 65-71.

IEA. (2016). The TIMSS 2015 International Results in Mathematics. Retrieved from https://www.iea.nl/studies/iea/timss/2015/results.

Karaçam, S., \& Baran, A. D. (2015). The Effects of Field Dependent/Field Independent Cognitive Styles and Motivational Styles on Students' Conceptual Understanding About Direct Current Circuits. Asia-Pacific Forum on Science Learning and Teaching, 16(2), 1-19.

Mefoh, P. C., Nwoke, M. B., \& Chijioke, J. B. C. C. A. O. (2017). Effect of Cognitive Style 
and Gender on Adolescents' Problem Solving Ability. Journal of Thinking Skills and Creativity, 25, 47-52. https://doi.org/10.1016/j.tsc. 2017.03.002.

Mullis, I. V. S., Martin, M. O., Gonzalez, E. J., \& Chrostowski, S. J. (2004). TIMSS 2003 International Mathematics Report. In IEA. Retrieved from https://timss.bc.edu/timss2003i/mathD.html.

NCTM. (2000). Principles and Standards for School Mathematics. United States of America: NCTM.

OECD. (2019). PISA 2018 Results: What Students Know and Can Do. New York: OECD Publishing.

Pithers, R. T. (2006). Cognitive Learning Style: A Review of the Field Dependent-Field Independent Approach. Journal of Vocational Education and Training, 54(1), 117132. https://doi.org/10.1080/13636820200200191.

Polya, G. (1957). How To Solve It: A New Aspect of Mathematical Method. https://doi.org/10.2307/j.ctvc773pk.

Puspendik. (2017). Capaian Nilai Ujian Nasional Matematika SMP Tahun Ajaran 2016/2017. Retrieved from https://hasilun.puspendik.kemdikbud.go.id/.

Puspendik. (2018). Capaian Nilai Ujian Nasional Matematika SMP Tahun Ajaran 2017/2018. Retrieved from https://hasilun.puspendik.kemdikbud.go.id/.

Ulya, H., \& Retnoningsih, A. (2014). Analysis of Mathematics Problem Solving Ability of Junior High School Students Viewed From Students' Cognitive Style. International Journal of Education and Research, 2(10), 577-582.

Volkova, E. V., \& Rusalov, V. M. (2016). Cognitive Styles and Personality. Personality and Individual Differences, 99, 266-271. https://doi.org/10.1016/j.paid.2016.04.097.

Witkin, H. A., \& Goodenough, D. R. (1981). Cognitive Styles: Essence and Origins. Field Dependence and Field Independence. In Psychological issues.

Witkin, H. A., Moore, C. A., Goodenough, D. R., \& Cox, P. W. (1977). Field-Dependent and Field-Independent Cognitive Styles and Their Educational Implications. ETS Research 
Bulletin Series, 47(1), 1-64. 